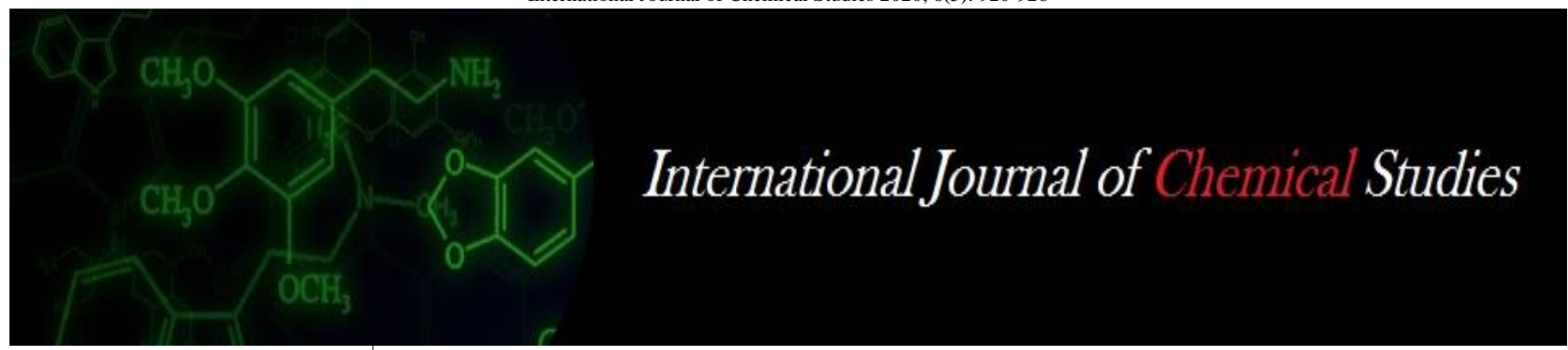

P-ISSN: 2349-8528

E-ISSN: 2321-4902

www.chemijournal.com

IJCS 2020; 8(5): 920-926

(C) 2020 IJCS

Received: 04-07-2020

Accepted: 08-08-2020

\section{Kanchana $\mathbf{N}$}

M.Sc. Student, Department of

Food Science and Nutrition,

Community Science College \&

Research Institute, Tamil Nadu

Agricultural University,

Madurai, Tamil Nadu, India

Veeranan Arun Giridhari V

Assistant Professor, Department of Textile Science and Design,

Community Science College and

Research Institute, Tamil Nadu

Agricultural University,

Madurai, Tamil Nadu, India

\section{Saravana Pandian $\mathbf{P}$}

Professor, Department of Soils and Environment, Agricultural College and Research Institute,

Tamil Nadu Agricultural

University, Madurai, Tamil

Nadu, India

\section{Vijayalakshmi R}

Assistant Professor, Department

of Human Development and

Family Studies, Community

Science College \& Research

Institute, Tamil Nadu

Agricultural University,

Madurai, Tamil Nadu, India

\section{Corresponding Author:}

Kanchana N

M.Sc. Student, Department of

Food Science and Nutrition,

Community Science College \&

Research Institute, Tamil Nadu

Agricultural University,

Madurai, Tamil Nadu, India

\section{Optimization of coagulant and proximate analysis of liquid whey from milk}

\author{
Kanchana N, Veeranan Arun Giridhari V, Saravana Pandian $\mathbf{P}$ and \\ Vijayalakshmi R
}

DOI: https://doi.org/10.22271/chemi.2020.v8.i5m.10416

\begin{abstract}
This study soughed to optimize the effective coagulant for high yield of whey from milk and evaluated the nutritional composition of whey. The coagulants used were citric acid, acetic acid and $\mathrm{Cacl}_{2}, \mathrm{CaSO}_{4}$ at different percentage. The coagulant results revealed that there was significant $(\mathrm{P}>0.05)$ differences between the yield of various coagulated whey $(81.1 \pm 0.09$ to $84.0 \pm 0.39 \%)$ however acid whey recorded higher yield than salty whey. The $\mathrm{pH}$ revealed that there was significantly differ between the acid whey and salty whey $(6.40 \pm 0.04$ to $5.19 \pm 0.10)$. The lactic acid $(\%)$ in salty whey $(0.14 \pm 0.00 \%)$ was scored low value compared to acid whey $(0.25 \pm 0.00 \%)$. The salty whey $(10.5 \pm 0.01 \%)$ was significantly higher in TSS content compared to acid whey $(6.4 \pm 0.00 \%)$. This study was concluded that, T7 $(0.13 \%$ acetic acid) was best in terms of yield $(84.7 \pm 0.44 \%)$ and sensory evaluated. The physiochemical parameters of $\mathrm{T} 7$ showed that the total solids, moisture, protein, fat, lactose, total ash, and total carbohydrate were $8.8 \pm 0.23 \%, 91.2 \pm 0.37 \%, 0.289 \pm 0.00 \%, 0.13 \pm 0.00 \%, 4.288 \pm 0.12 \%, 0.3892 \pm 0.00 \%$ and $7.991 \pm 0.04 \%$.
\end{abstract}

Keywords: Milk, whey, coagulants, acetic acid, citric acid, calcium salts

\section{Introduction}

Whey protein is considered the gold standard in terms of its protein biological value (BV) and quality therefore whey is best choice for those looking to protein supplements (Hemant et al., 2018) ${ }^{[8]}$. Whey proteins are present in small quantity but have a high PER (3.6), NPU (95), biological value (104) and as compared to all other protein sources available they are next to egg protein in terms of nutritive value (Ruann et al, 2017) ${ }^{[5]}$. It is rich in many essential amino acids (Savarana et al., 2005) ${ }^{[24]}$ especially branched-chain amino acids (BCAA) such as Leucine, and provides a balanced supply of the sulphuric amino acids, methionine and cysteine. Whey quickly found its place as an ingredient to increase lean muscle mass. (Kerry Institute) ${ }^{[1]}$ Whey is the liquid fraction that remains following manufacture of cheese, chhana, paneer and casein by the process called coagulation or acidification and which is discarded as waste material. It contains organic components that cause serious pollution to the soil as it imposes a very high BOD of 30,000-50,000 mg/lit and COD of 60,000-80,000 mg/lit. (Kriti Sharma et al., 2018; Gupta, 2008) ${ }^{[6,25]}$ Even thought it contains about $55 \mathrm{~g} / 100 \mathrm{~g}$ of the total ingredients of milk as lactose, soluble proteins, lipids and mineral salts, so it is now considered a valuable product rather than a waste product. For that reason, it was utilized in food processing sectors (Mollea et al., 2013) ${ }^{[12]}$ Acid whey is produced by the generation or direct addition of acids and results in the precipitation of caseins. Sweet whey comes from rennet coagulated cheese when caseins are removed. (Caessens et al., 1999) ${ }^{[10]}$ The pH and Lactic acid $\%$ of native, sweet, acid and salty whey are $6.5 \pm 0.03,6.4 \pm 0.02,4.2 \pm 0.02,5.5 \pm 0.01$ and $0.001 \pm 0.00,0.1 \pm 0.03,0.2 \pm 0.02,0.07 \pm 0.00$ respectively. (Chandrajith et al., 2018) ${ }^{[7]}$ Based on the percentage of lactic acid, the minerals and fractions of whey protein constitutes are distinct. Lactose (milk sugar) is a main component present in $70 \%$ and whey proteins, fat, mineral, water soluble vitamins are in moderate to low amount on dry matter content. (Irena $2018)^{[3]}$ The fractions of whey proteins are 37.9-49.0\% $\beta$-lactoglobulin ( $\beta$-LG), $11.3-16.5 \% \alpha$ lactalbumin ( $\alpha$-LA), 3.0-5.0\% bovine serum albumin (BSA), 5.0-8.0\% immunoglobulins and proteose peptone as well as several minor proteins including 1.3-1.8\% lactoferrin, lactollin, glycoproteins, lactoperoxidase and transferrin. (Kriti Sharma et al., 2018; Hemant et al., 2018) $[6,8]$. 
Whey nutritional compositions are total solids (6-7\%), protein (0.4-0.8\%), lactose (4.4-4.9\%), minerals and ash (0.5-0.8\%)

${ }^{[8]}$. Sweet whey nutrient compositions are total solids $(16.8 \%$ $\pm 0.01)$, protein $(10.8 \% \pm 0.4)$, lactose $(2.9 \% \pm 0.03)$, and ash $(0.7 \% \pm 0.08)$. Acid whey contains total solids $(2.86 \% \pm$ $0.07)$, protein $(1.73 \% \pm 0.01)$, lactose $(0.7 \% \pm 0.02)$, and ash $(0.21 \% \pm 0.01)$ (Chandrajith et al., 2018) ${ }^{[7]}$ Whey beverages are generally classified into four basic types: mixtures of whey (processed or unprocessed, including UF permeates) with fruit or (rarely) vegetable juices; dairy-type, 'thick' beverages (fermented or unfermented); thirst-quenching carbonated beverages (the 'Rivella-type'); and alcoholic beverages (beer, wine or liqueurs) (Castro et al., 2017) ${ }^{[5]}$. WPCs are available in various protein concentration levels such as 34\% (WPC34), 50\% (WPC50), or 80\% (WPC80). WPI is the purest form of whey protein and contains $90 \%$ or greater protein with minimal lactose $(<1 \%)$. WPH are predigested, partially hydrolyzed more easily absorbed (Morr et al., 1993) [14]. Whey protein powders helps enhancing performance during endurance exercise and increased muscle recovery. Several studies support the notion that only indispensable or essential amino acids are necessary to stimulate muscle protein synthesis and suggest that a protein which provides a high proportion of these amino acids will be efficient in promoting muscle growth. (Garlick et al., 1988) ${ }^{[11]}$. It also recommended for healthy aging, dietic foods and infant formulations ${ }^{[1]}$. It is a combination of protein easy to digest for HIV/AIDS people. Animal studies revealed that it increase the glutathione level in HIV/AIDS people's body tissues (Moreno et al, 2006; Aniruddha et al., 2010) ${ }^{[2,9]}$ and also bioactive peptides plays role in chronic diseases management [6]. In order to improve the shelf life and increasing the economic value, technologies has been introduced to produce whey powder, whey protein concentrate, whey protein isolate, and isolation of valuable protein fractions such as $\alpha$-lactalbumin ( $\alpha$-La) (Smithers 2015) ${ }^{[4]}$ The large volumes of whey can be processed into bioethanol, but the production of whey-based beverages proved to be the most economical and simple way of whey utilization. (Ruann et al, 2017) ${ }^{[5]}$

\section{Materials and methods}

This study was carried out in Community Science College and Research Institute, Madurai-Tamil Nadu-India. The fresh farm milk was purchased from the Agricultural College and Research Institute, Madurai-Tamil Nadu-India. The selected analytical food grade chemical coagulants such as calcium sulphate $\left(\mathrm{CaSo}_{4}\right)$, calcium chloride $\left(\mathrm{Cacl}_{2}\right)$, Citric acid and Acetic Acid were obtained from the Laboratory. The physiochemical parameters of pasteurized farm milk such as $\mathrm{pH}$, Acidity, Total Soluble Solids (TSS), Total solids, moisture content, protein, lactose, fat and ash content were investigated. Then, it was stored at refrigerated temperature $\left(4^{0} \mathrm{C} \pm 1\right)$ upto used (less than 5 hours).

\section{Optimization of coagulants}

The fresh farm milk was heated at $90^{\circ} \mathrm{C}$ for $5-10$ minutes in a stainless steel vessel with continuous stirring by using stirrer. The coagulants such $\mathrm{CaSo}_{4}(0.3 \%, 0.5 \%), \mathrm{Cacl}_{2}(0.3 \%, 0.5 \%)$, citric acid $(0.2 \%$ and $0.3 \%)$ and acetic acid $(0.13 \%, 0.15 \%)$ with different propositions were added into the heated milk with slow stirring until the coagulation or acidification was done. The coagulated casein (Paneer) was filtrated through cleaned muslin cloth and the liquid whey was collected into the vessel. The pH, Total Soluble Solids (TSS), Titratable
Acidity (Lactic acid \%), weight of coagulated casein (g), quantity of whey obtained (g) were analysed.

\section{Preparation of solutions}

The $0.3 \mathrm{~g}$ and $0.5 \mathrm{~g}$ of $\mathrm{CaSO}_{4}$ was dissolved in remaining proposition of cleaned water and made it as $0.3 \%$ and $0.5 \%$ solution respectively. Likewise $\mathrm{Cacl}_{2}(0.3 \%$ and $0.5 \%)$ and citric acid $(0.2 \%$ and $0.3 \%)$ were prepared. The $98 \%$ of acetic acid was used for the preparation of $0.13 \%$ and $0.15 \%$ of solutions. The solutions were dissolved by using magnetic stirrer for 10 minutes and transferred to the sterile glass beakers and covered with aluminum foil. The solutions were kept at ambient room temperature upto used.

\section{Protocol for whey preparation}

The fresh farm milk was heated upto $90{ }^{\circ} \mathrm{C}$ for 5-10 minutes in a stainless steel vessel with continuous stirring by the stirrer. The heated milk was cooled down to $82-85^{\circ} \mathrm{C}$. The optimized percentage of acetic acid $(0.13 \%)$ solution was slowly added into the hot milk at the temperature of $82^{\circ} \mathrm{C}$ with slow stirring until the acidification was done. It was kept upto 10 minutes without disturbing for complete coagulation. The whey liquid was separated from the coagulated casein by filtration throught pre-sterile muslin cloth. The obtained whey was pasteurized at $85^{\circ} \mathrm{C}$ for 10 minutes and hot filled in sterile PET bottles. The bottled whey was kept in storage at $\left(4^{0} \mathrm{C} \pm 1\right)$ for further analysis.

\section{Milk heated at $90^{\circ} \mathrm{C}$ (with stirring)

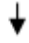 \\ Addition of $0.13 \%$ Acetic Acid at $82^{\circ} \mathrm{C}$ \\ $\downarrow$ \\ Allow 10 mins for complete coagulation (without stirring) \\ $\downarrow$ \\ Filtration of casein through clean muslin Cloth \\ $\downarrow$ \\ Pasteurization of liquid whey at $85^{\circ} \mathrm{C}$ for $5 \mathrm{mins}$ \\ Bottling in PET at $70^{\circ} \mathrm{C}$ \\ $\downarrow$ \\ Kept at $4^{\circ} \mathrm{C} \pm 1$ refrigerated temperature}

Fig 1: Steps involved preparation of whey from milk

\section{Proximate analysis}

The moisture content, $\mathrm{pH}$ (using digital $\mathrm{pH}$ meter) and total ash content in dry basis were estimated as per the procedure given by AOAC (1997) ${ }^{[15]}$. Titratable acidity (TA) of samples was determined by visual titration method (Ranganna, 1986) [23]. The total solid was estimated by Gravimetric method. (IS 12333 - 1997 / ISO 6731: 1989) ${ }^{[16]}$ The fat content was analysed by Gerber method. (IS 1479 - Part I/1961) ${ }^{[17]}$ The protein was analyzed by Micro Kjeldhal method given by AOAC 991.2. ${ }^{[18]}$. The lactose (milk sugar) content in milk products was measured by Lane Eynon method (volumetric method). The total carbohydrates were determined by using the method in I.S $1656-1997{ }^{[19]}$ Total Energy $(\mathrm{kcal} / 100 \mathrm{~g})=$ Protein $\%$ x 4 + Fat $\%$ x $9+$ Carbohydrate $\%$ x $4^{[20]}$.

\section{Sensory analysis}

The sensory evaluation was performed using 9-point hedonic scale analysis (Larmond, 1977) ${ }^{[22]}$. The samples were previously stabilized at $4^{0} \mathrm{C} \pm 1$ for 1 hour and presented the 
samples in sensory cups with $30 \mathrm{ml}$. The samples were coded with random numbers. Each sample were analysed individually and evaluated in triplicate. The sensory profile included the color, taste, odor, consistency and overall acceptability. The intensity of perception was mentioned on 0-9 scale point, where 0 represented extremely dislike extremely and 9 represented like extremely of perception.

1-2 Dislike Extremely

2-3 Dislike Very Much

3-4 Dislike Moderately

4-5 Dislike Slightly

5-6 Like Slightly

6-7 Like Moderately

7-8 Like Very Much

8-9Like Extremely

\section{Storage study}

The obtained sample was transferred into the PET bottles and stored for studied the stability of sample during storage period of 21 days both ambient temperature $\left(30 \pm 2{ }^{\circ} \mathrm{C}\right)$ and refrigerated temperature $\left(4 \pm 1^{0} \mathrm{C}\right)$. The $\mathrm{pH}$, Acidity (\% lactic acid), TSS and turbidity were analysed at $0^{\text {th }}$ day, $7^{\text {th }}$ day, $14^{\text {th }}$ day and $21^{\text {st }}$ day of both room temperature and refrigerated temperature.

\section{Statistical analysis}

The collected data were analysed by using AGRES software.

\section{Result and Discussion}

Nutritional composition of fresh cow milk

Table1 presented the proximate composition of pasteurized farm milk. The $\mathrm{pH}$, acidity (\% lactic acid) and TSS of farm milk was $6.5,0.13$ and 11 respectively. The moisture, protein, fat and lactose present in milk $87.7 \%, 3.7 \%, 4.1 \%$ and $5 \%$.

The total solids content of farm milk was $10.6 \%$ which was closely related to $11.4 \pm 1.4 \%$ (Enb, et al. 2009) ${ }^{[21]}$. The ash content of farm was 0.69 , which was correspondence with $0.52 \pm 0.01 \%[21]$

Table 1: Proximate composition of fresh farm milk

\begin{tabular}{|c|c|c|}
\hline S. No & Parameters & Farm milk \\
\hline 1 & $\mathrm{pH}$ & $6.5 \pm 0.12$ \\
\hline 2 & Acidity (\% lactic acid) & $0.13 \pm 0.00$ \\
\hline 3 & Total Soluble Solids ( ${ }^{0}$ Brix) & $11 \pm 0.08$ \\
\hline 4 & Total Solids (\%) & $10.6 \pm 0.06$ \\
\hline 5 & Moisture (\%) & $87.7 \pm 1.65$ \\
\hline 6 & Total solids (\%) & $12.03 \pm 0.06$ \\
\hline 7 & Protein (\%) & $3.7 \pm 0.05$ \\
\hline 8 & Fat (\%) & $4.1 \pm 0.03$ \\
\hline 9 & Lactose (\%) & $5.0 \pm 0.00$ \\
\hline 10 & Ash (\%) & $0.69 \pm 0.01$ \\
\hline
\end{tabular}

Value represents mean of four replication readings with standard deviations.

\section{Optimization of coagulants}

Coagulation of heated milk was done with different coagulants at two different propositions like $\mathrm{CasO}_{4}(0.3 \%$, $0.5 \%), \mathrm{Cacl}_{2}(0.3 \%, 0.5 \%)$, citric acid $(0.2 \%, 0.3 \%)$ and acetic acid $(0.13 \%, 0.15 \%)$. The table 2 shows the effect different coagulants on yield of whey and paneer. The Calcium salts coagulated whey values were $81.1 \pm 0.09 \%$ (T1), $81.6 \pm 1.34 \%$ (T2), $81.1 \pm 1.48 \%$ (T3), $81.7 \pm 2.11 \%$ (T4). There was no significant different between the yield of calcium salts coagulated whey. T7, T8 and T5 were the best treatment among all others; yield of whey was $84.0 \pm 0.39 \%$, $84.7 \pm 0.44 \%$ and $83.0 \pm 1.32 \%$. There was no significant difference among these three samples. And T7 is highest performing treatment among all other treatments. Rajashekar et al., 2016 reported that the yield of paneer made with citric acid was higher $(17.65 \%)$ compared to paneer made from acetic acid as a coagulant.

The author concluded that this result was indirectly related to the percentage of whey. The study results showed that the yield of acid coagulated whey was more comparatively calcium salts. The study concluded that acid was the efficient coagulant comparatively calcium salts. And also efficiency of coagulation depends on effectiveness of coagulants used. Fig.1. showed the difference between the yield of paneer and whey obtained by using different propositions of different coagulants.

Table 2: Yield of whey and paneer using different coagulants [\%]

\begin{tabular}{|c|c|c|c|}
\hline S. No & Treatments & Yield of whey (\%) & Yield of paneer (\%) \\
\hline 1 & T1 & $81.1 \pm 0.09^{\mathrm{c}}$ & $18.9 \pm 0.26^{\mathrm{a}}$ \\
\hline 2 & T2 & $81.6 \pm 1.34^{\mathrm{c}}$ & $18.4 \pm 0.02^{\mathrm{ab}}$ \\
\hline 3 & T3 & $81.1 \pm 1.48^{\mathrm{c}}$ & $18.9 \pm 0.04^{\mathrm{a}}$ \\
\hline 4 & T4 & $81.7 \pm 2.11^{\mathrm{c}}$ & $18.3 \pm 0.19^{\mathrm{b}}$ \\
\hline 5 & T5 & $83.0 \pm 1.32^{\mathrm{abc}}$ & $17.0 \pm 0.47^{\mathrm{c}}$ \\
\hline 6 & T6 & $82.5 \pm 0.58^{\mathrm{bc}}$ & $17.5 \pm 0.04^{\mathrm{c}}$ \\
\hline 7 & T7 & $84.7 \pm 0.44^{\mathrm{a}}$ & $15.3 \pm 0.00^{\mathrm{e}}$ \\
\hline 8 & T8 & $84.0 \pm 0.39^{\mathrm{ab}}$ & $16.0 \pm 0.35^{\mathrm{d}}$ \\
\hline
\end{tabular}

Value represents mean of four replication readings. Value with the same superscript letter(s) within the same column is not significantly different $(\mathrm{p}>0.05)$. T1 - 0.3\% Caso4, T2 - 0.5\% Caso4, T3 - $0.3 \%$ $\mathrm{Cacl}_{2}, \mathrm{~T} 4-0.5 \% \mathrm{Cacl}_{2}, \mathrm{~T} 5-0.2 \%$ citric acid, T6 $-0.3 \%$ citric acid, $\mathrm{T} 7-0.13 \%$ acetic acid, $\mathrm{T} 8-0.15 \%$ acetic acid 


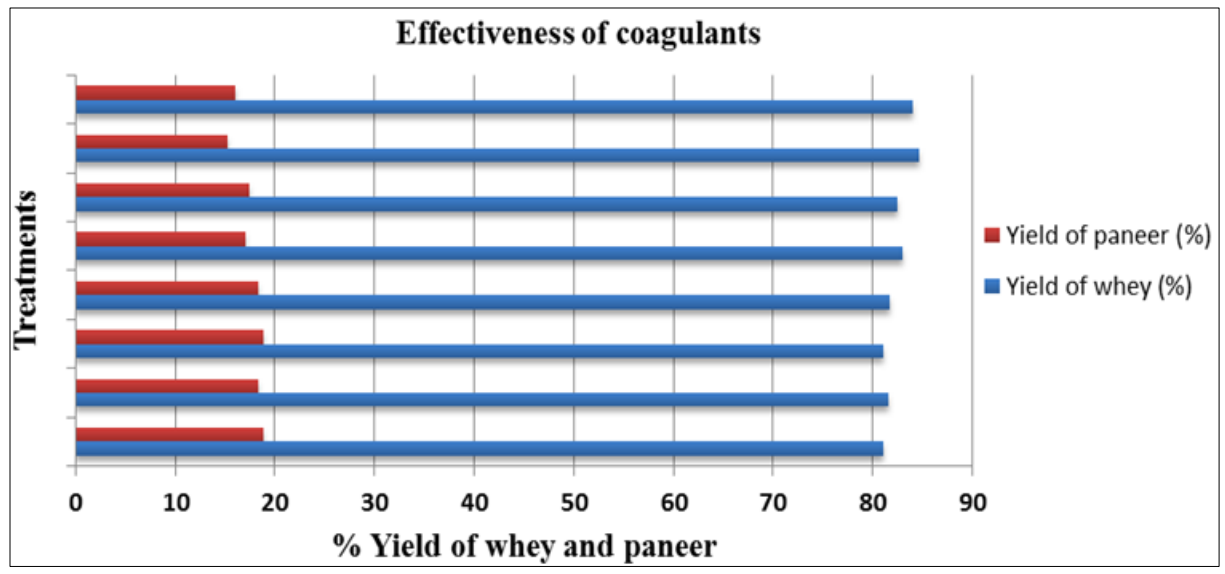

Fig 2: Yield of whey and paneer using different coagulants [\%]

$\mathrm{T} 1$ - 0.3\% Caso 4 ; 2 - 0.5\% Caso 4 T3 - 0.3\% $\mathrm{Cacl}_{2} ; \mathrm{T} 4$ $0.5 \% \mathrm{Cacl}_{2} ; \mathrm{T} 5-0.2 \%$ citric acid; T6 $-0.3 \%$ citric acid; $\mathrm{T} 7$ $0.13 \%$ acetic acid; $\mathrm{T} 8-0.15 \%$ acetic acid.

\section{Physicochemical parameters of whey}

Table 3 investigated the physicochemical parameters such as $\mathrm{pH}$, acidity and TSS of obtained different whey samples. There was no significant different of $\mathrm{pH}$ of whey between the T1 (6.40 \pm 0.04$)$ and T2 (6.31 \pm 0.14$)$ samples. And there was no significant difference of $\mathrm{pH}$ between the T5 (5.28 \pm 0.14$)$, T6 (5.25 \pm 0.08$), \mathrm{T} 7(5.21 \pm 0.11)$ and $\mathrm{T} 8(5.19 \pm 0.10)$. The result revealed that, acid coagulated whey posses the low $\mathrm{pH}$ (5.19-5.28) compared to calcium salt coagulated whey (6.4$6.15)$.

The acidity result showed that, acid coagulated whey posses the high $\%$ of lactic acid $(0.21 \pm 0.00 \%$ to $0.25 \pm 0.00 \%)$ compared to calcium salt coagulated whey $(0.14 \pm 0.00 \%$ to $0.18 \pm 0.00 \%$ ).

The titrable acidity (\% of lactic acid) results were negatively correlated with $\mathrm{pH}$ of the samples. Total soluble solids ( $\left.{ }^{0} \mathrm{Brix}\right)$ content of $\mathrm{T} 1$ was 10.5 which was highest than other experimental treatments. There was no significant difference of TSS between T5 $(6.9 \pm 0.01)$, T6 $(6.7 \pm 0.01)$ and T7 $(6.4 \pm 0.10)$, T8 $(6.43 \pm 0.00)$. The results of TSS showed that calcium coagulated whey $(8.9 \pm 0.22$ to $10.5 \pm 0.01)$ have highest TSS compared to acid coagulated whey (6.9 \pm 0.01 to $6.9 \pm 0.01)$.

And also, calcium salts coagulated whey was sweeter than acid coagulated whey. There was an indirect relationship between the TSS content and Acidity (\% of lactic acid).

Table 3: Physicochemical parameters of whey using different coagulants [\%]

\begin{tabular}{|c|c|c|c|c|}
\hline $\begin{array}{c}\text { S. } \\
\text { No }\end{array}$ & Treatments & $\mathbf{p H}$ & $\begin{array}{c}\text { Titrable acidity } \\
(\text { Lactic acid \%) }\end{array}$ & TSS $\left({ }^{\mathbf{0}} \mathbf{B}\right)$ \\
\hline 1 & $\mathrm{~T} 1$ & $6.40 \pm 0.04^{\mathrm{a}}$ & $0.14 \pm 0.00^{\mathrm{h}}$ & $10.5 \pm 0.01^{\mathrm{a}}$ \\
\hline 2 & $\mathrm{~T} 2$ & $6.31 \pm 0.14^{\mathrm{ab}}$ & $0.15 \pm 0.00^{\mathrm{g}}$ & $9.6 \pm 0.18^{\mathrm{b}}$ \\
\hline 3 & $\mathrm{~T} 3$ & $6.23 \pm 0.05^{\mathrm{bc}}$ & $0.16 \pm 0.00^{\mathrm{f}}$ & $8.1 \pm 0.21^{\mathrm{d}}$ \\
\hline 4 & $\mathrm{~T} 4$ & $6.15 \pm 0.01^{\mathrm{c}}$ & $0.18 \pm 0.00^{\mathrm{e}}$ & $8.9 \pm 0.22^{\mathrm{c}}$ \\
\hline 5 & $\mathrm{~T} 5$ & $5.28 \pm 0.14^{\mathrm{d}}$ & $0.21 \pm 0.00^{\mathrm{c}}$ & $6.9 \pm 0.01^{\mathrm{e}}$ \\
\hline 6 & T6 & $5.25 \pm 0.08^{\mathrm{d}}$ & $0.22 \pm 0.00^{\mathrm{b}}$ & $6.7 \pm 0.01^{\mathrm{e}}$ \\
\hline 7 & T7 & $5.21 \pm 0.11^{\mathrm{d}}$ & $0.23 \pm 0.00^{\mathrm{d}}$ & $6.4 \pm 0.10^{\mathrm{f}}$ \\
\hline 8 & T8 & $5.19 \pm 0.10^{\mathrm{d}}$ & $0.25 \pm 0.00^{\mathrm{a}}$ & $6.43 \pm 0.00^{\mathrm{f}}$ \\
\hline
\end{tabular}

Value represents mean of four replication readings. Value with the same superscript letter(s) within the same column is not significantly different ( $\mathrm{p}>0.05)$. T1 - 0.3\% Caso4, T2 - 0.5\% Caso4, T3 - 0.3\% $\mathrm{Cacl}_{2}, \mathrm{~T} 4-0.5 \% \mathrm{Cacl}_{2}, \mathrm{~T} 5-0.2 \%$ citric acid, T6 $-0.3 \%$ citric acid, $\mathrm{T} 7-0.13 \%$ acetic acid, $\mathrm{T} 8-0.15 \%$ acetic acid

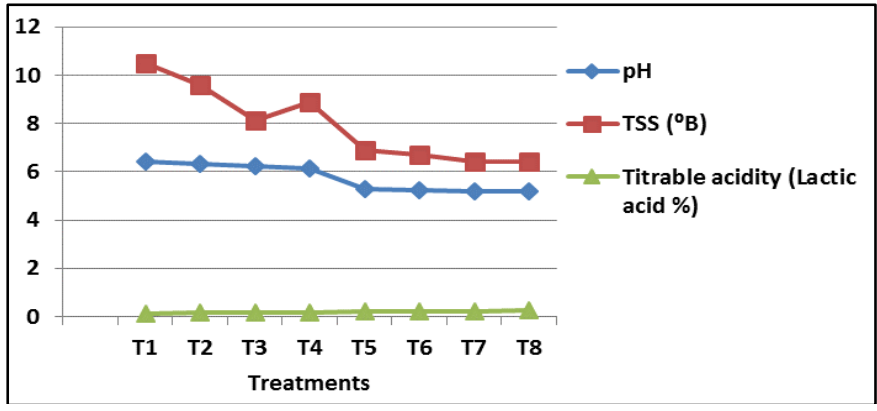

Fig 3: Comparison of pH, TSS, \% lactic acid of different treatments

$\mathrm{T} 1$ - 0.3\% Caso $;$ T2 - 0.5\% $\mathrm{Caso}_{4} ; \mathrm{T} 3$ - 0.3\% $\mathrm{Cacl}_{2} ; \mathrm{T} 4-$ $0.5 \% \mathrm{Cacl}_{2} ; \mathrm{T} 5-0.2 \%$ citric acid; T6 $-0.3 \%$ citric acid; T7 $0.13 \%$ acetic acid; $\mathrm{T} 8-0.15 \%$ acetic acid.

Table 4: Sensory evaluation of whey obtained by using various coagulants [\%]

\begin{tabular}{|c|c|c|c|c|c|c|}
\hline $\begin{array}{c}\text { S. } \\
\text { No }\end{array}$ & Treatments & Color & Taste & Odor & Consistency & $\begin{array}{c}\text { Overall } \\
\text { acceptability }\end{array}$ \\
\hline 1 & T1 & $5 \pm 0.12^{\mathrm{d}}$ & $5 \pm 0.05^{\mathrm{c}} 4 \pm 0.09^{\mathrm{d}}$ & $7 \pm 0.02^{\mathrm{b}}$ & $5 \pm 0.04^{\mathrm{d}}$ \\
\hline 2 & T2 & $6 \pm 0.08^{\mathrm{c}}$ & $4 \pm 0.14^{\mathrm{d}} 4 \pm 0.14^{\mathrm{d}}$ & $7 \pm 0.14^{\mathrm{b}}$ & $4 \pm 0.04^{\mathrm{e}}$ \\
\hline 3 & T3 & $5 \pm 0.04^{\mathrm{d}}$ & $5 \pm 0.15^{\mathrm{c}}$ & $4 \pm 0.17^{\mathrm{d}}$ & $7 \pm 0.26^{\mathrm{b}}$ & $5 \pm 0.05^{\mathrm{d}}$ \\
\hline 4 & T4 & $6 \pm 0.00^{\mathrm{c}}$ & $4 \pm 0.09^{\mathrm{d}} 4 \pm 0.13^{\mathrm{d}}$ & $7 \pm 0.02^{\mathrm{b}}$ & $4 \pm 0.04^{\mathrm{e}}$ \\
\hline 5 & T5 & $6 \pm 0.14^{\mathrm{c}}$ & $7 \pm 0.23^{\mathrm{b}}$ & $7 \pm 0.01^{\mathrm{a}}$ & $8 \pm 0.18^{\mathrm{a}}$ & $6 \pm 0.20^{\mathrm{c}}$ \\
\hline 6 & T6 & $7 \pm 0.22^{\mathrm{c}}$ & $7 \pm 0.05^{\mathrm{b}} 7 \pm 0.17^{\mathrm{b}}$ & $8 \pm 0.32^{\mathrm{a}}$ & $8 \pm 0.18^{\mathrm{a}}$ \\
\hline 7 & T7 & $8 \pm 0.33^{\mathrm{a}}$ & $7 \pm 0.15^{\mathrm{a}} 7 \pm 0.08^{\mathrm{b}}$ & $8 \pm 0.30^{\mathrm{a}}$ & $8 \pm 0.23^{\mathrm{a}}$ \\
\hline 8 & T8 & $7 \pm 0.14^{\mathrm{b}}$ & $6 \pm 0.05^{\mathrm{b}}$ & $6 \pm 0.32^{\mathrm{c}}$ & $8 \pm 0.03^{\mathrm{a}}$ & $7 \pm 0.20^{\mathrm{b}}$ \\
\hline
\end{tabular}

Value represents mean of triplicates readings. Value with the same superscript letter(s) within the same column is not significantly different ( $\mathrm{p}>0.05)$. T1 - 0.3\% Caso4, T2 - 0.5\% Caso4, T3 - 0.3\% $\mathrm{Cacl}_{2}, \mathrm{~T} 4-0.5 \% \mathrm{Cacl}_{2}, \mathrm{~T} 5-0.2 \%$ citric acid, T6 $-0.3 \%$ citric acid, $\mathrm{T} 7-0.13 \%$ acetic acid, $\mathrm{T} 8-0.15 \%$ acetic acid

Table 4 showed the sensory evaluation of sample treated with different coagulants. The overall acceptability of samples $\mathrm{T} 1$, $\mathrm{T} 2$, T3 and T4 were $5 \pm 0.04,4 \pm 0.04,5 \pm 0.05$ and $4 \pm 0.04$. These treatments of coagulated whey possessed the chemical note of the respective calcium salts. And gave the tartness of the samples may be due to the chemicals impurity. There was no significant difference among the sample T6 and T7. T7 has highest color perception, T, T6 and T7 has the highest taste and odor perceptions.

There was slight deviation in consistency between acid coagulated (T5, T6, T7, T8) and calcium salts coagulated (T1, T2, T3, T4) whey. T6 $(8 \pm 0.18)$ and T7 $(8 \pm 0.23)$ scored the highest overall acceptability among all other experimental treatments. The sensory evaluation result showed that T6 $(0.3 \%$ citric acid $)$ and $\mathrm{T} 7(0.13 \%$ acetic acid $)$ treated whey 
scored best rank. This is due to the addition of acids into the whey, which balanced the taste.

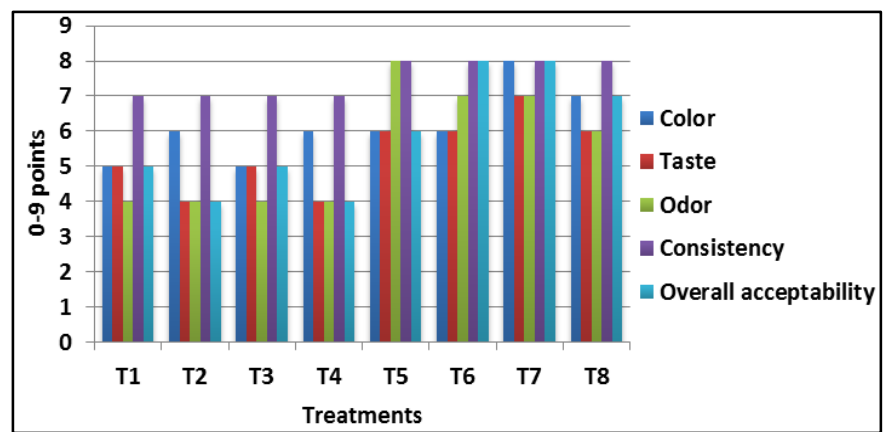

Fig 4: Sensory evaluation of treated samples

$\mathrm{T} 1$ - 0.3\% Caso $;$ T2 - 0.5\% Caso 4 T3 - 0.3\% $\mathrm{Cacl}_{2} ; \mathrm{T} 4$ $0.5 \% \mathrm{Cacl}_{2} ; \mathrm{T} 5-0.2 \%$ citric acid; T6 $-0.3 \%$ citric acid; $\mathrm{T} 7$ $0.13 \%$ acetic acid; $\mathrm{T} 8-0.15 \%$ acetic acid

The results of optimization of coagulants revealed that $\mathrm{T} 7$ has the best treatment for yielding the high $\%$ of whey. And the sensory evaluation concluded the T6 and T7 samples were scored the highest rank. Form the results, $\mathrm{T} 7$ has been selected as best treatment in terms of sensory and percentage of whey obtained.

\section{Nutritional profile of selected sample}

Table 5 showed the nutritional composition of selected T7 $(0.13 \%$ acetic acid) coagulated whey. The $\mathrm{pH}$ was 5.21 and the percentage of latic acid was $0.23 \%$. The result was indicated that, obtained whey comes under medium acid whey category. Generally, during manufacturing of paneer, acid whey was obtained. TSS content of whey was $6.4^{0}$ Brix. The amount of total soluble solids is due to the \% of lactose (milk sugar) content present in whey. During acidification, lactose was converted into lactic acid; this was responsible for high percentage of lactic acid among others except T8. And the amount of lactose in acid whey was $4.288 \%$. Comparatively acid whey contains is less amount lactose than sweet whey. Moisture content was $91.2 \%$, due to watery portion of milk was separated during coagulation/acidification. A total solid includes protein, carbohydrates, minerals, water soluble vitamins and fat. The percentage of solids present in whey was $8.8 \%$ which is also respect to the effectiveness of coagulants. The protein content was $0.289 \%$ comprises of major and minor fractions of whey.

The concentrated whey contains higher percentage of whey proteins (WPC, WPI and WPH). The total ash content of whey is $0.389 \%$. Acid whey contains low amount of fat percentage 0.13 .

The acidity of whey is the main factor responsible for formulating the beverages includes less $\mathrm{pH}$.

Table 5: Proximate composition of whey using the $0.13 \%$ of acetic acid coagulant

\begin{tabular}{|c|c|c|}
\hline S. No & Parameters & Whey [\%] \\
\hline 1 & $\mathrm{pH}$ & $5.21 \pm 0.13$ \\
\hline 2 & Total Soluble Solids $\left({ }^{0}\right.$ Brix) & $6.40 \pm 0.09$ \\
\hline 3 & Titrable Acidity (Lactic acid \%) & $0.23 \pm 0.00$ \\
\hline 4 & Total solids & $8.8 \pm 0.23$ \\
\hline 5 & Moisture & $91.2 \pm 0.37$ \\
\hline 6 & Protein & $0.289 \pm 0.00$ \\
\hline 7 & Total Ash & $0.3892 \pm 0.00$ \\
\hline 8 & Lactose & $4.288 \pm 0.12$ \\
\hline 9 & Fat & $0.13 \pm 0.00$ \\
\hline 10 & Total carbohydrates & $7.991 \pm 0.04$ \\
\hline
\end{tabular}

Value represents mean of four replication readings with standard deviations.

\section{Storage study}

\section{Effect of acidity during storage periods}

Fig.5. illustrated that the effect acidity during room temperature. The \% of lactic acid was gradually increased in all the treatments.

The changes of acidity in sample $\mathrm{T} 7$ was increased from the initial stage $(0.23 \%)$ to $(0.28 \%)$ at the end of storage period. Fig.6. showed that effect of acidity during refrigerated temperature. The changes of acidity in sample T7 was increased from the initial stage $(0.23 \%)$ to $(0.25 \%)$ at the end of storage period.

The increase of acidity is may be due to action of lactic acid on sugar and protein content. Production of organic acids and amino acids lead to an increase in acidity thereby a decrease in $\mathrm{pH}$, as also reported for mango based beverages (Kalra $e t$ al., 1991; Sikder et al., 2001).

The whey based orange beverage has an initial titratable acidity of $0.112 \%$ in terms of citric acid and increases to $0.148 \%$ citric acid after 3 months of storage when stored after addition of preservative (Chatterjee et al., 2015) The initial acidity of the WMB $(0.405 \%)$ had increased to $0.435 \%$ after
30 days of storage.

This increase in acidity was due to the conversion of lactose to lactic acid. (Chavan et al., 2015)

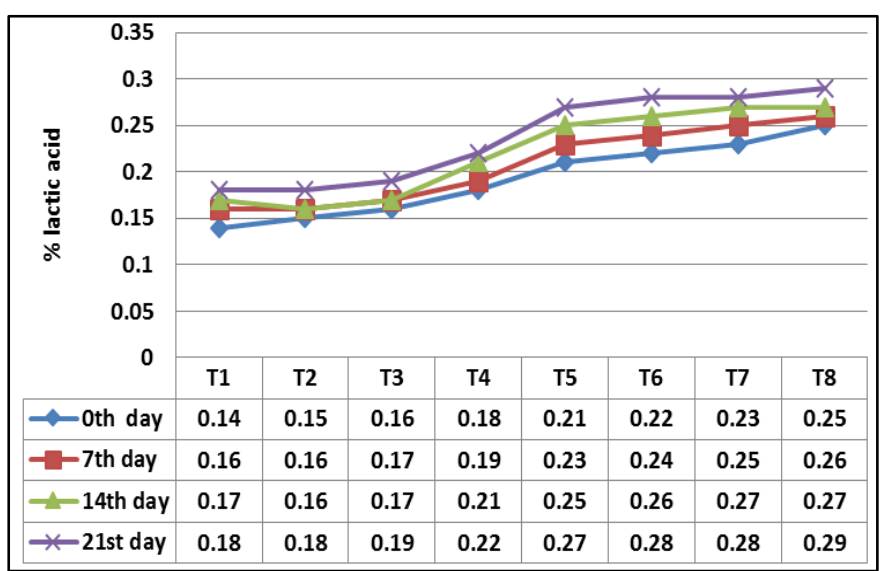

Fig 5: Effect of acidity (\%) during storage periods at ambient temperature $\left(30 \pm 2^{\circ} \mathrm{C}\right)$ 


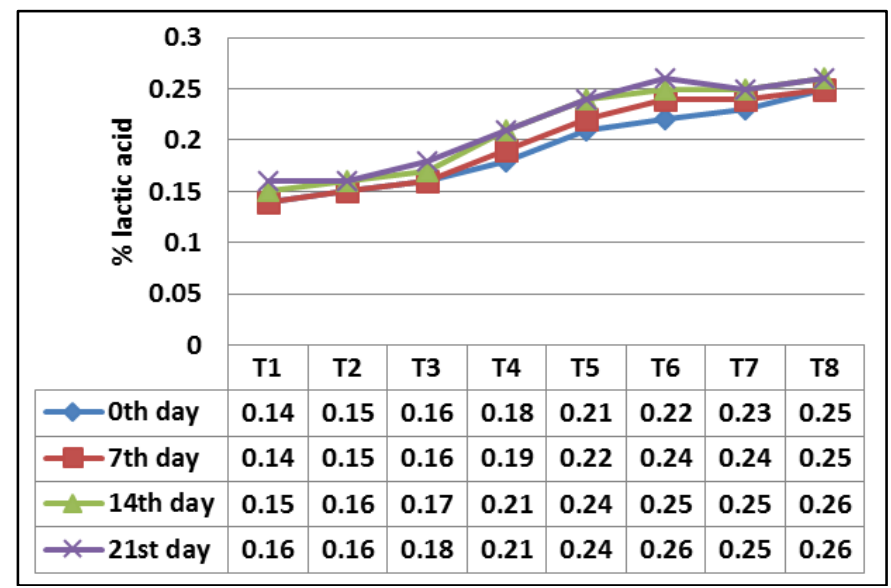

Fig 6: Effect of acidity (\%) during storage periods at refrigerated temperature $\left(4 \pm 1^{\circ} \mathrm{C}\right)$

\section{Effect of TSS during storage periods}

Fig.7. pictured about the TSS content of samples stored at room temperature.

The TSS content of all samples was gradually increased during storage periods. TSS content of T7 sample was increased from 6.4 to 6.5 .

The increase in TSS during storage is also reported in ready to serve beverage developed from guava nectar by Murari et al., 1989. Fig.8. showed that TSS content of samples during storage periods. TSS content of T7 sample was increased from 6.4 to 6.6 .

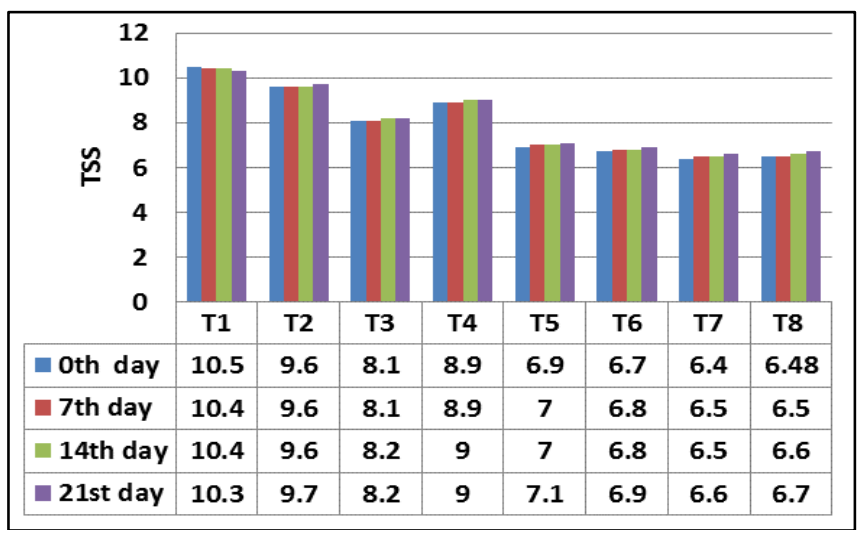

Fig 7: Effect of TSS during storage during ambient temperature

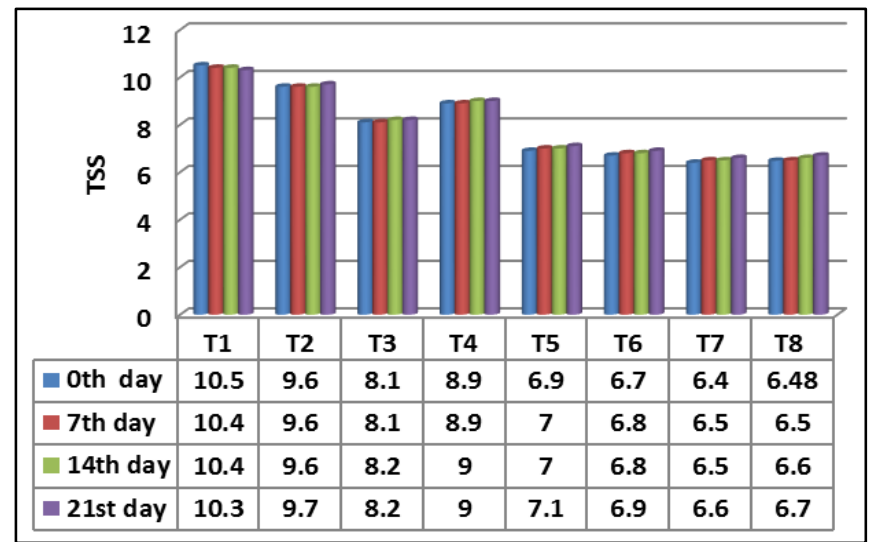

Fig 8: Effect of TSS during storage during refrigerated temperature

\section{Conclusion}

Utilization of whey powder in food products such as supplements and beverages is gaining improvement in food industries. In spite of using concentrated whey powders, liquid whey is feasible to formulated low cost nutritious food products especially beverages. And also it helps effectively reduce the organic pollution to the soil due to discard of whey. Commercially available whey powder supplements are high in cost. The acetic acid $(0.13 \%)$ is the one of the best coagulant, for obtaining more percentage of whey during coagulation of milk. And also, it increases the \% of lactic acid of whey. Acid whey is best suited for the formulations beverages due to their natural acidity compared to sweet whey and native whey.

\section{Reference}

1. Sara Llamas Moya, M.Sc., Ph.D. - Global Applications Manager for Animal and Pet Nutrition, Kerry Health and Nutrition Institute.

2. Moreno Y.F., Sgarbieri V.C., da Silva M.N., Toro A.A., Vilela M. M. Features of whey protein concentrate supplementation in children with rapidly progressive HIV infection. J Trop Pediatr. 2006; 52(1):34-8.

3. Irena Barukcic, Whey as a Potential Functional FoodProperties, Processing and Future Perspective, Journal of Food Biotechnology Research. 2018; (2)1:2.

4. Smithers GW. Whey-ing up the options - Yesterday, today and tomorrow. Int Dairy J. 2015; 48:2-14.

5. Castro Ra, Domingues M, Ohara A, Okuro P, Santos J, Brexó $\mathrm{R}$ et al. Whey protein as a key component in food systems: Physicochemical properties, production technologies and applications, Food Structure. 2017; (14):17-29

6. Sharma K, Chauhan ES. Multifaceted Whey Protein: Its Applications in Food Industry, International Journal of Health Sciences \& Research. 2018; (8)10.

7. Chandrajith VGG, Karunasena GADV. Applications of Whey as A Valuable Ingredient in Food Industry, Journal of Dairy \& Veterinary Sciences. 2018; 6(5).

8. Hemant H Gangurde. Mayur A Chordiya, Pooja S Patil, Nayana S Baste, Whey protein, Scholars' Research Journal. 2011; 1(2)

9. Aniruddha Bhati, KH Khan. Whey protein and its application to human, Journal of Experimental Sciences. 2010; 1(1):16-20

10. Caessens P, Daamen WF, Gruppen H, Visser S, Voragen AG. Betalactoglobulin hydrolysis. Peptide identification, SH/SS exchange, and functional properties of hydrolysates fractions formed by the action of plasmin. $\mathbf{J}$ Agric Food Chem. 1999; 47:2980-90.

11. Garlick PJ, Grant I. Amino acid infusion increases the sensitivity of muscle protein synthesis in vivo to insulin. Effect of branched-chain amino acids. Biochem J. 1988; 254:579-84.

12. Mollea Chiara, Bosco Francesca, Marmo Luca. Valorisation of cheese whey, a by-product from the dairy industry. INTECH Open Access Publisher, 2013.

13. Haug A, Hostmark AT, Harstad OM. Bovine milk in human nutrition - A review. Lipids Health Dis. 2007; 6:25.

14. Morr CV, Ha EY. Whey protein concentrates and isolates: Processing and functional properties. Crit Rev Food Sci Nutr. 1993; 33:431-76.

15. AOAC (Association of Official Analytical Chemists). Official methods of analysis of the association of official analytical chemistry. 16th (Eds.), Washington. 1997; 2:235-236. 
16. Milk, Cream and Evaporated milk. - Determination of total Solids Content -reference method. IS 12333 - 1997 / ISO 6731: 1989, Bureau of Indian Standards, New Delhi.

17. Manual of Food Quality Control, 14/8, page 8 / IS 1479 (Part I) 1961(Reaffirmed 2003) Methods of test for Dairy Industry - Rapid Examination of Milk. Bureau of Indian Standards, New Delhi

18. Ma T, Zuazaga G. Estimation of protein. In: Ranganna, S. (Ed), Analysis and quality control for fruits and vegetables products. Tata McGraw Hill, 1942, 2ndedn.

19. Milk cereal based Weaning foods - Specification. IS 12333 - 1997 / ISO 6731: 1989 Bureau of Indian standard, New Delhi

20. Merrill AL, Watt BK. Energy value of foods: basis and derivation. Agriculture handbook 74. Washington, DC: US Department of Agriculture, Agricultural Research Service, 1973.

21. Enb A, Donia MAA, Abd-Rabou NS, Abou-Arab AAK, El-SenaityEnb MH. Chemical composition of raw milk and heavy metals behavior during processing of milk products. Global Veterinaria. 2009; 3(3):268-275.

22. Larmond E. Laboratory Methods for Sensory Evaluation of Foods. Canada Department of Agriculture, Pub., 1977, 1637.

23. Ranganna S. Manual of Analysis of Fruit and Vegetable Products. Tata McGraw Hill Publishing Company Ltd. New Delhi, 1986, 7-12.

24. Saravana KR, Manimegalai G. Studies on storage stability of whey based papaya juice blended RTS beverage. Journal of Food science and technology. 2005; 42(2):185-188.

25. Gupta VK. Over view of production, processing and utilization of dairy by products. Course Compendium: Technological advances in the utilization of dairy Products.15-16, Dec. 2008, National Dairy Research Institute, KARNAL, HARYANA (India). 2008, 1-7. 